\title{
AS CARACTERÍSTICAS ARQUETÍPICAS E SUAS RESSONÂNCIAS NOS ORIXÁS FEMININOS DA UMBANDA
}

\author{
Maria Antônia Lima Pavei ${ }^{1}$ \\ Gutemberg Alves Geraldes Junior ${ }^{2}$
}

\section{Resumo}

A Umbanda apresenta, em algumas ramificações, a presença do culto aos Orixás, nas quais, utilizam-se de mitos e símbolos da mitologia iorubá, trazida pelos escravos africanos da cultura nagô-yorubá. Esta crença traz, em suas lendas, a expressão feminina como protagonista, representada pelas Yabás, sendo as mais cultuadas no rito umbandista: (a) Iemanjá; (b) Iansã; (c) Oxum e (d) Nanã, conhecidas também como as mães d'água. Em suas narrativas mitológicas, elas apresentam características humanas, sendo suscetíveis às incertezas, gerando, dessa forma, uma identificação humana com as entidades sagradas, norteada neste artigo pelo comportamento psíquico da mulher. $\mathrm{O}$ presente estudo busca analisar as representações simbólicas dos Orixás femininos, diante de seus mitos, símbolos e pontos cantados, apresentados na obra de Ademir Barbosa Júnior (2014) e Janaína Azevedo (2010). Ao identificar os fatores predominantes que singularizam cada Yabá, fundamenta-se, com base na psicologia analítica desenvolvida por Carl Gustav Jung (2000), o conceito de inconsciente coletivo e sua ancestralidade. $O$ estudo realizado dá-se por meio de uma pesquisa qualitativa descritiva e tem como objetivo identificar os padrões individuais de cada Orixá e, a partir disso, reconhecer a similaridade arquetípica de cada uma, dentre os dezesseis arquétipos trazidos à luz sob o olhar das pesquisadoras Mark e Pearson (2001). Entende-se, dessa forma, que ao reconhecer os padrões de cada personalidade, o inconsciente coletivo identifica esses símbolos, destacando uma característica predominante em cada Orixá; sendo Iemanjá, a Grande Mãe; Nanã como Mago; Iansã, o Herói e Oxum, a Amante.

Palavras-chaves: Arquétipo, Umbanda, Yabás, Inconsciente Coletivo.

\section{ARCHETYPICAL CHARACTERISTICS AND THEIR RESONANCES IN THE FEMALE ORIXÁS OF UMBANDA}

\begin{abstract}
Umbanda presents, in some branches, the presence of the Orixás cult, in which myths and symbols from Yoruba mythology are used, brought by the African slaves of the Nagô-Yoruba culture. This belief brings in its legends, the feminine expression as protagonist, represented by the Yabás, being the most worshiped in the umbandista rite: (a) Iemanjá; (b) Iansã; (c) Oxum and (d) Nanã, also known as the water mothers. In their mythological narratives, they have human characteristics, being susceptible to uncertainties, thus generating a human identification with the sacred entities, guided in this article by the woman's psychic behavior.

\footnotetext{
${ }^{1}$ UNISATC. Graduada em Publicidade e Propaganda pela UNISATC. ORCID http://orcid.org/0000-0001-66605342. E-mail: mariaantoniapavei@gmail.com

${ }^{2}$ Professor titular da disciplina de Estética da Comunicação e coordenador do curso de Publicidade e Propaganda da UNISATC. Doutor em Ciências da Linguagem pela Universidade do Sul de Santa Catarina (UNISUL). ORCID http://orcid.org/0000-0002-2266-3919. E-mail: gutemberg.geraldes@satc.edu.br
} 
This study seeks to analyze the symbolic representations of the female Orixás, in view of their myths, symbols and sung points, presented in the work of Ademir Barbosa Júnior (2014) and Janaína Azevedo (2010). When identifying the predominant factors that make each Yabá unique, the concept of the collective unconscious and its ancestry is based, based on the analytical psychology developed by Carl Gustav Jung (2000). The study carried out here, takes place through a descriptive qualitative research and aims to identify the individual patterns of each Orixá and, from that, recognize the archetypal similarity of each one, among the sixteen archetypes brought to light under the eye by researchers Mark and Pearson (2001). It is understood, therefore, that when recognizing the patterns of each personality, the collective unconscious identifies these symbols, highlighting a predominant characteristic in each Orixá, with Iemanjá being the Great Mother, Nanã as Mage, Iansã the Hero and Oxum the Lover.

Keywords: Archetype, Umbanda, Yabás, Collective Unconscious.

\section{INTRODUÇÃO}

As mulheres são, historicamente, coadjuvantes e invisibilizadas no universo das tradições religiosas, no entanto, existe uma ruptura deste contexto nas religiões de matriz africana, na qual, elas se tornam protagonistas na relação com o sagrado. Na mitologia iorubá, apresentada por Rose Marie Muraro (2014), a figura da mulher tem um papel relevante na narrativa da criação, sendo ela a provedora da existência dos orixás. Essa narrativa permanece presente nas religiões atuais de raiz africana, como a Umbanda, que em seu sincretismo adotou o culto aos diversos deuses representados pela natureza.

Existe uma identificação emocional significativa entre a médium ${ }^{3}$ e as Yabás $^{4}$, isso ocorre pela assimilação das mulheres com as características femininas que as entidades carregam em suas personalidades. Carl Gustav Jung (2000) explica essa identificação, com personalidades da narrativa mitológica, por meio dos arquétipos, que se caracterizam por ser uma ferramenta que busca traçar perfis psicológicos, presentes no inconsciente coletivo, que são enfatizados em situações rotineiras da vida humana, fazendo com que ocorra a identificação de um público com personagens que se ocupam de tais características. Para Reginaldo Prandi (2001), as religiões dos orixás têm seus valores encontrados nos conhecimentos míticos que falam por meio de símbolos e enigmas, assim como, apresentam os deuses e deusas como seres sobrenaturais com traços da personalidade humana.

\footnotetext{
${ }^{3}$ Pessoa detentora de dons que supostamente lhe permitem conhecer coisas, dados, ocorrências etc. por meios sobrenaturais.

${ }^{4}$ Cujo significado é Mãe Rainha, é o termo dado aos orixás femininos.
} 
Diante da colocação de identificação da mulher com as Yabás, presentes na Umbanda, este artigo busca, como objetivo geral, responder ao seguinte questionamento: de que forma as características arquetípicas encontram ressonância nos Orixás femininos da Umbanda? Para responder a essa questão, serão analisadas as características das Yabás, levando em consideração sua história mitológica e símbolos representativos, em seguida, para dialogar com a questão, será exposto um breve estudo sobre o inconsciente coletivo na visão de Jung (2000) e os arquétipos apresentados por Mark e Pearson (2001); sendo esses os objetivos específicos.

Esta pesquisa assume uma abordagem qualitativa descritiva, utilizando como base a análise de conteúdos, com o intuito de ampliar ou complementar o conhecimento sobre a psique humana, neste caso, especificamente do gênero feminino, e como esse processo mental envolve a assimilação de personagens, sejam eles do âmbito da comunicação ou religioso.

Sendo a Umbanda a religião desta pesquisadora e o feminino, gênero ao qual ela se identifica, desde o primeiro momento a mesma se reconheceu nas Yabás e notou esta reciprocidade entre outras médiuns do terreiro. Por este motivo, decidiu realizar tal pesquisa em nível científico com o intuito de compreender a comparação entre os Orixás femininos e o comportamento das mulheres. Além de a pesquisa representar, significativamente, um grupo que, até então é brevemente abordado em pesquisas científicas, também se coloca em prática aspectos teóricos abordados no curso de Publicidade e Propaganda, que analisam tanto o cotidiano da comunicação, como também temas antropológicos, auxiliando assim na compreensão das dinâmicas sociais que engendram e influenciam o mercado publicitário criciumense e sua evolução.

\section{MITO FUNDADOR DA UMBANDA}

Entre os mitos fundadores da Umbanda, o de destaque está na origem da religião com Zélio de Morais, no Rio de Janeiro. A narrativa passa por variações, porém encontramos na obra Os Decanos: os fundadores, mestres e pioneiros da Umbanda, Saraceni (2003), uma pressuposta narrativa, com detalhes de como seria a iniciação desta religião.

O mito é uma realidade cultural extremamente complexa, que pode ser abordada e interpretada em perspectivas múltiplas e complementares. [...] O mito conta uma história sagrada, relata um acontecimento que teve lugar no tempo primordial, o tempo fabuloso dos começos (ELIADE, 2000, p.12). 
De acordo com Saraceni (2003), com apenas 17 anos, Zélio de Morais já havia concluído o ensino médio e estava se preparando para ingressar na Escola Naval, foi nesse momento que o jovem começou a apresentar comportamentos tidos como estranhos.

Ora ele assumia a estranha postura de um velho, falando coisas aparentemente desconexas, como se fosse outra pessoa e que havia vivido em outra época; e, em outras ocasiões, sua forma física lembrava um felino lépido e desembaraçado, que parecia conhecer todos os segredos da natureza, os animais e a plantas (SARACENI, 2003, p. 21).

Preocupada, a família procurou auxílio na medicina, na igreja católica e, por último, o encaminharam para a recém fundada Federação Kardecista de Niterói. Foi nesse encontro, realizado no dia 15 de novembro de 1908, que Zélio incorporou o Caboclo das Sete Encruzilhadas. O espírito respondeu a uma série de perguntas e em uma delas, feita por Sr. José, é questionado se já não existiriam religiões suficientes.

[...] vocês homens preconceituosos, não contentes em estabelecer diferenças entre os vivos, procuram levar essas mesmas diferenças até mesmo além da barreira da morte. Por que não podem nos visitar esses humildes trabalhadores do espaço, se, apesar de não haverem sido pessoas importantes na terra, também trazem importantes mensagens do além? Por que o "não" aos caboclos e pretos-velhos? Acaso não foram eles também filhos de Deus? (SARACENI, 2003, p. 22).

Ao fim das indagações, o espírito anuncia a fundação da Umbanda, que seria concretizada no dia seguinte, na casa de Zélio, como nos mostra Saraceni (2003, p. 23):

Haverá uma mesa posta a toda e qualquer entidade que queira ou precise se manifestar, independente daquilo que haja sido em vida, todos serão ouvidos e nós aprenderemos com aqueles espíritos que souberem mais e ensinaremos àqueles que souberem menos e a nenhum viraremos as costas e nem diremos não, pois esta é a vontade do Pai.

Destaca-se que, desde sua origem, a Umbanda afirma-se como uma religião miscigenada, valorizando a representação nacional com base na mestiçagem que Gilberto Freyre (2003), em sua obra Casa-grande \& Senzala, reconhece como o encontro sociocultural entre brancos, negros e índios. Porém, é importante ressaltar que no início, a religião não exibia traços dos cultos africanos, já existentes no Brasil. Esse sincretismo ocorreu durante a ramificação da Umbanda que levou à divergência entre os cultos. Na obra $O$ que é Umbanda, de Patrícia Birman (1985), ela afirma que voltamos a um velho problema:

a tensão entre a Unidade e a Multiplicidade [...]. As várias linhas de um mesmo riscado. As umbandas existentes são ricas em variações doutrinárias e seus 
participantes são exímios mestres em inovar, em assimilar influências, em compor rituais. Procedem, em suma, de acordo com o movimento duplo já apontado: manter uma certa unidade sem abrir mão das múltiplas variações. A autonomia dos centros é sem dúvida o ponto nodal dessa permeabilidade à variação que encontramos na Umbanda [...] (BIRMAN, 1985, p. 25).

Ainda que a prática seja a mesma, existem diferentes expressões, Ademir Barbosa Júnior (2014), em sua obra O livro essencial de Umbanda, apresenta dez vertentes. Começando com a Umbanda Tradicional, organizada por Zélio; em seguida, a Umbanda Popular, no qual ocorre um sincretismo entre os Orixás e santos católicos. Outras umbandas que se aproximam do Candomblé são a Umbanda Omolokô e Umbandomblé. A Umbanda de Caboclo e a de Pretos Velhos sofrem outras influências como das culturas indígenas e dos negros escravizados, denominados Pretos Velhos. Distantes das práticas tradicionais, citadas anteriormente, são a Umbanda Branca, Esotérica e Iniciática, nas quais, não são utilizados elementos africanos.

Barbosa Júnior (2014) afirma também que os Orixás são agentes divinos, verdadeiros ministros da Divindade Suprema, presentes nas culturas e tradições espirituais/religiosas, com nomes e cultos diversos.

Os Orixás conhecidos na Umbanda são os Ancestrais, subordinados a Jesus Cristo, governador do Planeta Terra. Os mais comuns na Umbanda são Oxalá, Ibejis, Obaluaê, Ogum, Oxóssi, Xangô, Iansã, Iemanjá, Nanã, Oxum (BARBOSA JÚNIOR, 2014, p. 81)

Cada um com características e atributos singulares que permitem a identificação deles perante os médiuns. Algumas particularidades são as cores, os elementos naturais regentes, o mito iorubá que traz a narrativa particular de cada Orixá, contada de forma oral pelos escravos; até mesmo a comida e o animal associado a eles são delimitações para distingui-los.

\subsection{AS YABÁS: EXPRESSÃO FEMININA NA UMBANDA}

A força do feminino está presente desde o mito iorubá sobre a criação, transferido das religiões ancestrais. Na introdução histórica do livro O Martelo das Feiticeiras, Muraro (2014) afirma que Nanã Buruquê é quem dá à luz todos os Orixás, sem auxílio de ninguém, constatando dessa forma como a representação feminina nas religiões de matriz africana é primordial.

O presente artigo abordará características das principais Yabás, nos cultos umbandistas, são elas: (a) Iemanjá; (b) Oxum; (c) Iansã e (d) Nanã. Para analisar suas particularidades será 
utilizada a obra O livro essencial de Umbanda, de Ademir Barbosa Júnior (2014), Orixás na Umbanda de Janaina Azevedo (2010) e Mitologia dos Orixás de Reginaldo Prandi (2001).

\begin{abstract}
Nanã é a mais velha das mães-d'água, [...] primeira esposa de Oxalá, aquela que lhe deu seus filhos primeiros, Ossaim, Omolu, Oxumarê, lansã e Ewá. [...] conta a lenda que quando Oxalá moldou o ser humano, tentou fazê-lo de várias formas [...]foi então que Nanã Buruku veio em seu socorro: do fundo do lago calmo e cheio de lodo onde ela morava, tirou uma farta porção de lama fértil e deu a Oxalá. Com essa lama cheia de vida, ele criou o homem (AZEVEDO, 2010, p. 96).
\end{abstract}

Sua saudação "Saluba, Nanã" significa "Salve a Senhora da Morte" ou também "Salve a Senhora da Lama", pois acredita-se que, após a morte, o corpo retorna para Nanã com o intuito de que o ciclo continue. Essa Orixá é a guardiã do saber ancestral, representada pela cor roxa, tem como símbolo, o Ibiri, apetrecho que aparece sempre em suas mãos e seu elemento natural é a lama, as águas primordiais como são conhecidas que aparece em seus contos.

[...] Mas tem um dia que o homem morre e seu corpo tem que retornar à terra, voltar à natureza de Nanã Burucu. Nanã deu a matéria no começo mas quer de volta no final tudo o que é seu. (PRANDI, 2001, p. 197).

Figura 1. Nanã

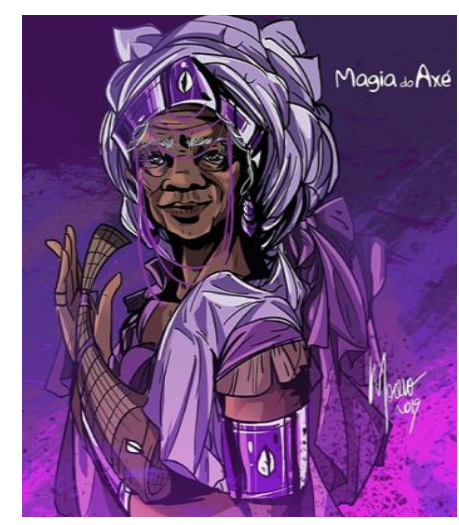

Fonte: Instagram Magia do Axé

Disponível em: https://www.instagram.com/magia_do_axe

Enquanto Nanã é sabedoria, Iansã é guerreira, leva em suas mãos seu raio e espada, tendo como seu elemento da natureza o fogo e seu nome significa mãe dos nove filhos. Esse universo nos é apresentado por Barbosa Júnior (2014, p. 129) quando em sua narrativa, ele apresenta Iansã como uma Orixá forte, e ainda, complementa:

Orixá guerreira, senhora dos ventos, das tempestades, dos trovões e também dos espíritos desencarnados (eguns) [...] Oya, é sensual, representando o arrebatamento, a paixão. De temperamento forte, foi esposa de Ogum, e depois a mais importante 
esposa de Xangô (ambos tendo o fogo como elemento afim). Irrequieta e impetuosa, é a senhora do movimento e, em algumas casas, também a dona do teto da própria casa.

Na Umbanda, ainda que pertencendo à chamada Linha d’Água, Iansã também se associa ao vento, às tempestades e ao tempo, tendo como cor alusiva o amarelo coral ou vermelho, sua saudação é "Eparre, Oyá", presente em pontos cantados nos terreiros que evocam a rainha dos ventos e dos relâmpagos.

[...] E quanto mais a guerra era terrível e mais urgia a fabricação das armas, mais forte soprava Oiá a forja de Ogum. Tão forte que às vezes destruía tudo no caminho, levando casas, arrancando árvores, arrasando cidades e aldeias. (PRANDI, 2001, p. 304).

Figura 2. Iansã

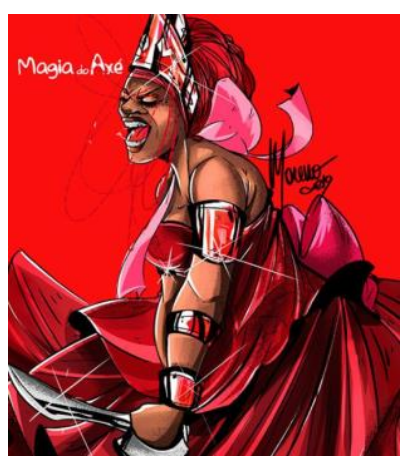

Fonte: Instagram Magia do Axé

Disponível em: https://www.instagram.com/magia_do_axe

Entre as Yabás pertencentes a esta linha, temos Iemanjá, considerada a mãe dos Orixás, senhora das águas e mãe dos deuses - cuja mitologia a apresenta como:

Um dia, com o pai ausente, Orungã violentou Iemanjá, que, estarrecida, fugiu em disparada, perseguida por ele. Quando estava prestes a ser alcançada, Iemanjá caiu. Seu corpo cresceu e cresceu, como vales e montanhas. Dos seios surgiram dois rios, que se juntaram numa lagoa, da qual se formou o mar. De seu ventre, que também havia crescido de modo incomum, nasceram os Orixás (BARBOSA JÚNIOR, 2014, p. 141).

É também considerada a mãe zelosa, grande mãe que veio com os negros da África para cuidar e amar. Ligada ao elemento água que está em todas as suas características, desde sua cor simbólica, o azul claro, até seu ponto de força, o mar, seu cumprimento é “Odoya”, que significa "Mãe das Águas".

Figura 3. Iemanjá 


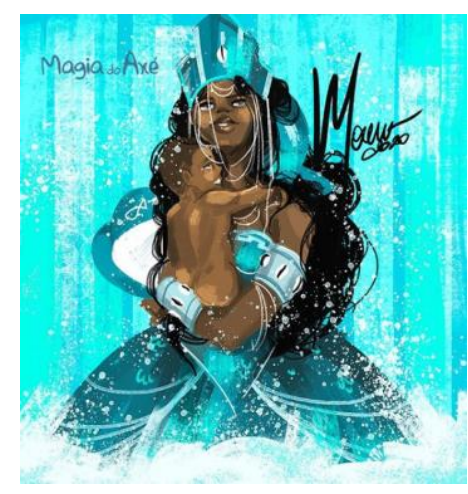

Fonte: Instagram Magia do Axé

Disponível em: https://www.instagram.com/magia_do_axe

No imaginário popular, é possível identificar atributos humanos a essa Yabá, como a feminilidade, sensualidade e erotismo, assim como para Oxum que é a filha de Oxalá com Iemanjá. A quem Barbosa Júnior (2014, p. 120) nos apresenta como:

Senhora do ouro (na África, cobre), das riquezas, do amor. Orixá da fertilidade, da maternidade, do ventre feminino, a ela se associam as crianças. Nas lendas em torno de Oxum, a menstruação, a maternidade, a fertilidade, enfim, tudo o que se relaciona ao universo feminino é valorizado.

A cor amarela, presente em suas vestes, está diretamente ligada ao seu metal, o ouro, sendo representada sempre com jóias e em sua mão carrega o espelho. Ao saudá-la falando “Oraieie ô, Oxum" reforça-se que ela é a "Senhora da Água Doce", conhecida assim por habitar as cachoeiras, os rios e lagos e, por vezes, encontra-se chorando.

Figura 4. Oxum

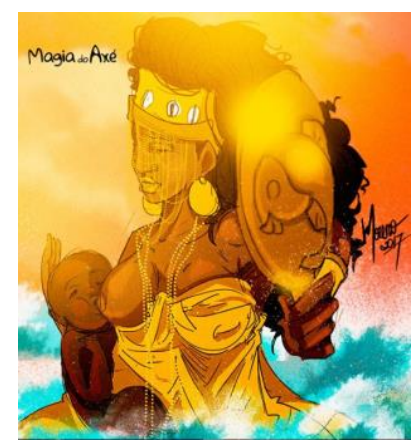

Fonte: Instagram Magia do Axé

Disponível em: https://www.instagram.com/magia_do_axe

Ao observar as individualidades apresentadas nas narrativas, é possível compreender que as Yabás carregam características humanas, tanto físicas como emocionais que vão além 
do caráter sagrado, gerando assim uma identificação e vinculação com situações existentes no inconsciente coletivo feminino.

\title{
2.2 O INCONSCIENTE COLETIVO NA NARRATIVA MITOLÓGICA
}

$\mathrm{Na}$ história das religiões, assim como nas culturas, certos padrões de funcionamento tornam-se dominantes. Essas reações têm suas raízes no passado da humanidade e seguem adiante pelas gerações. Certos conceitos universais assemelham-se em divergentes culturas, como nas mitologias e símbolos em comum. Essa similitude é explicada por Jung (2000), por meio do inconsciente coletivo:

O inconsciente coletivo é uma parte da psique que pode distinguir-se de um inconsciente pessoal pelo fato de que não deve sua existência à experiência pessoal [..] o inconsciente coletivo não se desenvolve individualmente, mas é herdado. Ele consiste de formas preexistentes, arquétipos, que só secundariamente podem tomarse conscientes, conferindo uma forma definida aos conteúdos da consciência (JUNG, 2000, p. 53-54).

Os conteúdos e imagens encontradas no inconsciente coletivo foram denominadas por Jung (2000) como Arquétipos e estão presentes na história simbólica dos mitos, nas instituições, nos costumes, entre outros e continuarão a ser representados através dos séculos.

\begin{abstract}
Há tantos arquétipos quantas situações típicas na vida. Intermináveis repetições imprimiram essas experiências na constituição psíquica[...] Quando algo ocorre na vida que corresponde a um arquétipo, este é ativado e surge uma compulsão que se impõe a modo de uma reação instintiva contra toda a razão e vontade (JUNG, 2000, p.58).
\end{abstract}

As reações instintivas que correspondente ao contato com os arquétipos explicam os padrões comportamentais humanos. Muraro (2014) explica, baseada nos estudos junguianos, que assim como no self ${ }^{5}$ individual, a sombra do self cultural é formada por símbolos complexos (conjunto de símbolos) que não foram devidamente elaborados e permaneceram inconscientes durante a história de cada indivíduo e de cada cultura.

Os arquétipos são as matrizes do funcionamento dos símbolos que expressam a normalidade e a patologia. [...] A psique humana tem arquétipos que são matrizes que coordenam a maneira como ela forma suas imagens e organiza seu funcionamento.

\footnotetext{
${ }^{5}$ Segundo Jung, o Self “[...]não é apenas o ponto central, mas também a circunferência que engloba tanto a consciência como o inconsciente. Ele é o centro dessa totalidade, do mesmo modo que o eu é centro da consciência" (JUNG, 1994, p. 51).
} 
Os principais arquétipos organizam até mesmo a maneira como o Eu se relaciona com o Outro na consciência, ou seja, como a consciência lida com os símbolos (MURARO, 2014, p. 22).

Dentro da narrativa histórica, é possível afirmar a presença significativa dos arquétipos nas mitologias e religiões. Eliade (2001), assim como Jung (2000), afirma que o homem é, historicamente, religioso, pois os seus ancestrais tiveram experiências religiosas que foram transmitidas inconscientemente.

Ao falar das vivências ancestrais, é notória a relevância simbólica, pois foi por meio desses códigos que as narrativas mitológicas surgiram como resposta aos questionamentos sociais, tanto no âmbito do autoconhecimento, quanto na explicação do surgimento do homem. No livro O Herói e o Fora da Lei, de Mark e Pearson (2001), é apontado que podemos entender os mitos e arquétipos como o impulso eterno de encontrar um significado do humano no mistério da criação.

\footnotetext{
Os contos de fadas e os mitos seriam como os sonhos de uma cultura inteira, brotando desse inconsciente coletivo. Os mesmos tipos de personagem parecem ocorrer, tanto na escala pessoal como na coletiva. Os arquétipos são impressionantemente constantes através dos tempos e das mais variadas culturas, nos sonhos e nas personalidades dos indivíduos, assim como na imaginação mítica do mundo inteiro (VOGLER, 2006, p. 48).
}

As expressões arquetípicas apresentadas em uma construção narrativa, neste caso, a mitológica, garante uma identificação e influência na psique humana. Dentre os diversos arquétipos, alguns são recorrentes nas narrativas, entre eles: o (a) Inocente, (b) Explorador, (c) Sábio, (d) Herói, (e) Fora-da-lei, (f) Mago, (g) Cara Comum, (h) Amante, (i) Bobo da Corte, (j) Criador e (k) Governante.

O primeiro arquétipo apresentado por Mark e Pearson (2001) é o do Inocente, conhecido por almejar o paraíso, como Aruanda no mito Nagô. Por sonhar com o lugar ideal que transmite alegria, ele torna-se otimista associando-se aos prazeres da vida e sendo ingênuo. Em contrapartida, o Explorador está sempre em busca de descobrir quem ele é, sentindo necessidade de desbravar ambientes e aventuras. Esta diferença é descrita como:

Enquanto o Inocente espera ser capaz de viver no paraíso, como direito seu ou devido a uma mudança de consciência, o Explorador sai em busca de um mundo melhor (MARK; PEARSON, 2001, p. 79).

Em seguida, vem o Sábio, usando sua inteligência e experiência para compreender o mundo e encontrar, à sua maneira, o paraíso. Sendo ele, o portador do conhecimento, é visto 


\section{Linguagens - Revista de Letras, Artes e Comunicação - ISSN 1981- 9943 \\ Blumenau, v. 15, n. 2, p. 153-173, maio./ago. 2021.}

também como conselheiro, mas gosta de, nesse processo, ser livre para pensar e assegurar suas opiniões. Esses três arquétipos buscam diferentes formas para conquistar a realização pessoal, porém, encontramos, em outros, um esforço em deixar sua marca no mundo, são eles: o Herói, o Fora-da-lei e o Mago.

[...]geralmente são os protagonistas destemidos que percebem seu poder especial e vão em frente, correndo grandes riscos pessoais a fim de mudar sua própria realidade. $\mathrm{Na}$ vida cotidiana, esses poderosos arquétipos proporcionam uma estrutura capaz de liberar, mas pessoas comuns, a capacidade de se erguer para enfrentar os desafios (MARK; PEARSON, 2001, p. 109).

Vogler (2015) explica que um Herói é alguém que está disposto a sacrificar suas próprias necessidades em benefício dos outros. É ele quem triunfa contra o mal, mesmo passando por desafios, inspirando dessa forma, a determinação e a disciplina. Em contraposto, encontra-se o Fora-da-lei, que nas palavras de Mark e Pearson (2001), enquanto o Herói quer ser admirado, o Fora-da-lei contenta-se em ser temido. Implantando o medo, esse arquétipo ganha poder para conquistar seus objetivos. Cordeiro, Damazio e Geraldes Junior (2019) apresentam que essas características são descritas por Jung (2000) como a Sombra, sendo, portanto, a metade escura da personalidade individual, como também, a personificação dos desejos hostis e gananciosos do inconsciente.

O Mago tem como característica básica ver as coisas acontecerem, para isso, utiliza das leis que regem a narrativa. Para Vogler (2006), ele é, também, uma figura que ajuda o Herói em sua jornada. Nas palavras de Mark e Pearson:

As aplicações mais típicas da sabedoria mágica são: curar a mente, o coração e o corpo; descobrir a fonte da juventude e o segredo da longevidade; descobrir meios de criar e manter a prosperidade; e inventar produtos que façam as coisas acontecerem (MARK; PEARSON, 2001, p. 148).

Além do desejo de conquista, observado nas personalidades anteriores, é possível encontrar nas narrativas mitológicas aqueles que almejam pertencer a um grupo, sendo este um desejo primordial ancestral humano. O Cara Comum é o arquétipo que representa esse princípio, pois ele adequa-se o suficiente para fazer parte de um grupo, para isto, ele vê valor nas pessoas e procura se encaixar tranquilamente, optando por símbolos comuns como roupas básicas.

Outro aspecto relevante para atrair um grupo é o sentimento. Para este atributo, definimos como arquétipo o Amante, ele representa o amor, a sexualidade e a intimidade. Nas 
histórias, é retratado de forma elegante e afetuosa, diferentemente, do Bobo da Corte que é retratado, de acordo com Cordeiro, Damazio e Geraldes Junior (2019), como o Pícaro, uma figura despreocupada, malandra, engraçada que aprecia uma brincadeira e uma confusão. Esse último traz em sua narrativa a interação com o próximo pelo prazer de poder ser ele mesmo, sem a autocrítica. Mark e Pearson apresentam um breve resumo sobre estes três arquétipos:

[...]Cara Comum ajuda a adicionar os comportamentos e perspectivas que nos permitem adquirir o senso de adequação suficiente para sermos parte do grupo [...] O Amante auxilia no processo de nos tornarmos atraentes para os outros e também nos ajuda a desenvolver as aptidões para a intimidade emocional e sexual. O Bobo da Corte nos ensina a viver com leveza, a viver no momento presente (MARK; PEARSON, 2001, p. 166).

A expressão arquetípica do Criador não tem problema em se enquadrar nos grupos sociais, sua meta pessoal é a auto expressão. São conhecidos como inovadores, podendo ser encontrados nas áreas artísticas, estando sempre em busca da criatividade, acreditando no poder da imaginação e de torná-las reais.

O arquétipo do Criador é visto no artista, no escritor, no inovador e no empresário, bem como em qualquer atividade que utilize a imaginação humana. A paixão do criador é a auto-expressão na forma material (MARK; PEARSON, 2001, p. 235).

Como exteriorização da personalidade autoritária, temos o Governante. Ele aparece como o pai, mãe e chefe. Sua característica primordial é a liderança, sendo responsável com seus objetivos. Nas palavras de Mark e Pearson (2001, p. 214):

O Governante assume o controle da situação, especialmente quando elas parecem estar fugindo do controle. É tarefa do Governador assumir a responsabilidade por tornar a vida o mais previsível e estável que for possível.

Para finalizar os doze principais padrões, apresentados por Mark e Pearson (2001), temos o Prestativo que está menos focado nos próprios problemas, pois tem uma preocupação consciente em ajudar o próximo. Ao longo do tempo, o Prestativo vem sendo associado à maternidade e paternidade. Jung (2000) apresenta um arquétipo semelhante, chamado por ele de Grande Mãe, que carrega consigo as características descritas como:

Seus atributos são o "maternal": simplesmente a mágica autoridade do feminino; a sabedoria e a elevação espiritual além da razão; o bondoso, o que cuida, o que sustenta, o que proporciona as condições de crescimento, fertilidade e alimento; o lugar da 
transformação mágica, do renascimento; o instinto e o impulso favoráveis (JUNG, 2000, p.92).

Outros arquétipos presentes nas análises junguianas são: (a) Persona, (b) Anima, (c) Animus e (d) Self. Para explicar a importância na psique humana, Jung (2000) afirma que estão ligados ao encontro com o consciente, quando, durante o cotidiano, ocorrem fatores que despertam a identificação. É nesse momento que os arquétipos são evocados e ganham um significado, gerando, desta forma, um reconhecimento pessoal com a personalidade apresentada.

\section{ANÁLISE}

O processo de reconhecimento do indivíduo em imagens mitológicas, conforme supracitado, é explicado por Jung (2008) como o processo de individuação que consiste em o indivíduo reconhecer, dentro de seus traços psíquicos, semelhanças com símbolos e personalidades, atribuindo, dessa forma, o senso de individualidade e assimilação. Por isso, Jung (2008) afirma ainda que essa identificação ocorre, principalmente, em contextos religiosos que trazem, para o consciente, a sensação de particularidade.

Na Umbanda, as personalidades que os frequentadores da religião se assimilam são os Orixás, tendo esse artigo como foco de pesquisa os Orixás femininos que carregam características individuais como Iemanjá que tem conexão com as mães por ter o atributo de zelosa e Nanã que tem ligação com as mulheres mais velhas por sua sabedoria e experiência.

Dessa forma, o relato da pesquisa, aqui, descrita tem seu foco nas manifestações arquetípicas das Yabás, dentro de suas narrativas individuais e padrões de personalidades que ocasionam na identificação das mulheres com as imagens dos Orixás femininos, representados nesse artigo por (a) Nanã, (b) Iansã, (c) Iemanjá e (d) Oxum; que em seus mitos apresentam além do sagrado, personificações humanas com polos negativos e positivos e que, por meio dos arquétipos, consegue-se reconhecer tão bem suas características.

\subsection{NANÃ BURUQUÊ: A YABÁ DA TRANSFORMAÇÃO}

Nanã Buruquê, conforme visto anteriormente, é a mais velha das Yabás e a primeira esposa de Oxalá, o Orixá responsável pela criação do mundo. Por ser a primeira Yabá, é 
considerada a portadora da sabedoria e experiência. Em seu mito iorubá, apresentado por Azevedo (2010), ela é uma grande rainha matriarcal, poderosa e conhecedora de muitas magias. Um dos seus feitos mais narrados foi ajudar Oxalá na criação, quando esse não encontrava um elemento na natureza para dar vida ao ser humano, foi Nanã que, oferecendo o barro como matéria prima, fez com que os seres fossem moldados. Evidencia-se aqui, sua característica primordial de transformação, em que a terra se mistura com a água da criação, virando a lama que dá sustentação para delinear o homem e a mulher.

Nesta lenda, percebe-se uma identificação da imagem arquetípica de Nanã com o Mago, que é apresentado por Mark e Pearson (2001). A principal característica que essas autoras destacaram nesta personificação é o de conhecedor das leis fundamentais que governam o funcionamento das coisas, aplicando esses princípios na prática, reforçando o atributo de mutação e renovação. Os magos, para Mark e Pearson (2001), estão na base das criações e envolvem rituais, usando da ciência, espiritualidade e psicologia para promover transformações.

Essa Orixá rege a maturidade e conhecimento, logo, na Umbanda, é procurada pelas médiuns que estão à procura de racionalidade para a tomada de decisões e conselhos objetivos, despertando a proximidade de Nanã em sua representação como Mago. Sua imagem simbólica é representada por uma senhora velha de rosto expressivo, nesse momento, quando é tomada como conselheira devido à sua sabedoria, ela tem ressonância ao arquétipo também do Sábio que, para Vogler (2006), é como um mentor que tem como função-chave ensinar e treinar o herói em sua jornada. Essa personalidade passa credibilidade e está ligada aos estudos e à lógica.

A canção Ponto de Nanã $\tilde{a}^{6}$, reproduzida por Mariene de Castro, exemplifica as características marcante destas Yabá:

\footnotetext{
Ela vem ao som da chuva

Dançando devagar seu ijexá

Senhora da Candelária, abá

Pra toda a sua nação iorubá

Oxumarê me deu dois barajás

Pra festa de Nanã

A velha deusa das águas
}

\footnotetext{
${ }^{6}$ Disponível em: https://www.youtube.com/watch?v=CWSG_zKRCKw
} 
O ponto cantado relata as particularidades de Nanã como paciência ao dançar devagar que reforça o processo de transformação atrelado a essa Yabá, ressaltando que esse é um processo lento que demanda conhecimento. No imaginário popular, suas características são similares às do Mago. Mark e Pearson (2001) afirmam que qualquer arquétipo pode se expressar em uma pessoa seja qual for a idade, dessa forma, uma criança em processo de aprendizagem e uma mulher adulta à procura de conselhos podem se identificar com Nanã, pois o inconsciente de ambas reconhecem nela os atributos do Mago, sendo eles, o conhecimento e a renovação.

\subsection{IANSÃ: A GUERREIRA ENTRE AS YABÁS}

Iansã irradia vibrações poderosas, por ser ela a senhora das tempestades e trovões, trabalhando à margem das leis e consciência. Barbosa Júnior (2014) apresenta essa Orixá como a responsável em conduzir os espíritos desencarnados (eguns) para outros planos, por ser seu filho, Egungun, o responsável pelo mundo dos mortos. Considerada uma Yabá de temperamento forte, é chamada de guerreira, levando consigo sua espada e raio. Reginaldo Prandi (2001), ressalta as características desta Yabá:

\footnotetext{
[...]Rainha que é Oiá Igbalé, a condutora dos eguns.

Oiá então dançou e dançou de alegria.

Para mostrar a todos seu poder sobre os mortos [...]
}

Esse Orixá feminino tem, em sua personalidade, traços que se assemelham ao arquétipo do Herói como bravura, superação e honra; representado na música, no momento em que Iansã, em um ato de coragem, leva, para longe, o mal, prevalecendo, assim, a paz. Segundo Vogler (2006), a raiz da ideia de Herói está ligada a um sacrifício de si mesmo com objetivo de seguir seus ideais, saindo da realidade limitante para constantes mudanças que o levam ao triunfo e a um mundo melhor.

As mulheres frequentadoras da Umbanda identificam-se com a força e coragem dessa Yabá. Nesse momento, o inconsciente reconhece estes traços como sendo típicos do Herói. Em suas lendas, Iansã, quando exerce a função maternal, deixa seus filhos para lutar, superando as adversidades em busca da justiça e do bem maior, sendo um comparativo ao cotidiano moderno, em que as mães deixam seus filhos para exercer seu trabalho ou as mulheres em busca dos seus direitos igualitários, assim como o Orixá, ambas dedicam-se a atitudes heroicas. 


\section{Linguagens - Revista de Letras, Artes e Comunicação - ISSN 1981- 9943 \\ Blumenau, v. 15, n. 2, p. 153-173, maio./ago. 2021.}

Em algumas narrativas, ela está relacionada ao seu marido Xangô, o justiceiro, porém, a identidade de independência permanece. Barbosa Júnior (2014) afirma que a liberdade do vento é considerada superior à vaidade, manifestando assim o arquétipo do Explorador que sente realização em aventuras que permitam o encontro consigo mesmo. Mark e Pearson (2001) apresentam essa personalidade como alguém insatisfeito que está em busca de um lugar melhor, sem limitantes para sua jornada.

Jung (2002) explica que os arquétipos são flexíveis, podendo ter em uma mesma personalidade a projeção de dois ou mais arquétipos que se manifestam de acordo o momento vivenciado. Dessa forma, mesmo com projeção do Explorador, em momentos mencionados no mito de Iansã, predomina-se os padrões que determinam o Herói como arquétipo dessa Yabá. As médiuns que se conectam com a personalidade de Iansã são ditas como audaciosas e corajosas, pois assim como a Orixá, elas lutam por sua independência e estão diretamente ligadas em causas para defender os indefesos, confirmando assim a personificação do herói.

\subsection{IEMANJÁ: ORIXÁ MAIS CULTUADA DO BRASIL}

Conhecida como a rainha das águas no imaginário popular, Iemanjá também é tida como mãe, enquanto Nanã Buruquê é considerada a criadora dos homens, Iemanjá é a que gerou os Orixás. Na obra de Azevedo (2010), é relatado que os negros africanos diziam que essa Yabá cuidava deles por ser mãe zelosa e protetora. Ela é responsável pela cabeça dos bebês e pela união da família, representada nas narrativas iorubá, em que Iemanjá é representada de forma maternal.

Esse arquétipo é apresentado por Jung (2002) como a Grande Mãe que, para ele, possui uma variedade incalculável de aspectos, sendo a mais louvada e o primeiro arquétipo que o inconsciente reconhece, pois declara que a mãe não é apenas a condição prévia física, mas também psíquica da criança. Eliade (2000) afirma que a Grande Mãe é encontrada em mitos que expressam o surgimento de algo ou nascimento divino, a mãe pode ser representada de três formas: a pessoa, geradora ou a pessoa que assume e herda essa imagem. No caso de Iemanjá, ela é a geradora dos Orixás e a que herda os aspectos maternais perante as mulheres que a levam como o símbolo de mãe defensora.

Em uma das lendas apresentadas por Barbosa Júnior (2014), ele afirma que Iemanjá tem como ponto da natureza o mar, sendo nomeada por Olorum, que é o ser supremo na mitologia iorubá, como a responsável por cuidar e proteger as praias, tendo assim, o controle sobre as 


\section{Linguagens - Revista de Letras, Artes e Comunicação - ISSN 1981- 9943 \\ Blumenau, v. 15, n. 2, p. 153-173, maio./ago. 2021.}

ondas. Por ser associada ao mar, os pescadores entregam na praia oferendas para ela, a fim de que sejam protegidos. O ritual, atualmente, ganhou mais adeptos, no dia dois de fevereiro, é de costume que as pessoas se reúnam para prestigiar Iemanjá. Essa narrativa também está presente no canto Dois de Fevereiro ${ }^{7}$, de Dorival Caymmi:

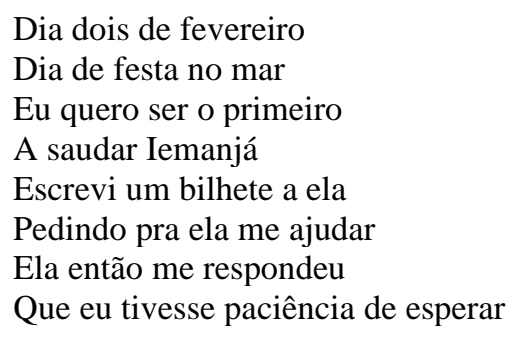

A senhora do mar, em seu simbolismo, exala respeito, cuidado e compaixão; como o arquétipo do Prestativo que é mencionado como uma personalidade generosa por Mark e Pearson (2001), deixando de lado as suas dificuldades pessoais, a fim de ajudar ao próximo, pois teme a instabilidade dos menos afortunados.

O instinto da compaixão, de cuidar e defender é uma das principais características das mulheres que com Iemanjá se assemelham, por vezes, encontram-se em situações de acolhimento ao próximo. A imagem expressada por essa Yabá no imaginário popular é reconhecida pelo inconsciente coletivo, proveniente da conexão dos escravizados que já identificavam em Iemanjá, a Grande Mãe, conduzindo essa identidade até os dias contemporâneos, comprovando assim que o inconsciente tem tendências inatas que prospectam de geração a geração.

\subsection{OXUM: YABÁ DO AMOR}

Filha preferida de Oxalá e Iemanjá, Oxum é conhecida por ser a Senhora do Ouro. Em sua narrativa mitológica, foi Oxalá quem a presenteou com o metal precioso, no qual, ela lava e cuida nas águas das cachoeiras e rios, onde costuma se banhar e pentear seus longos cabelos. Ela é a representatividade do amor, fertilidade, sensualidade e romance. Nas lendas apresentadas por Barbosa Júnior (2014), ela está sempre associada à maternidade e ao amor, como em seu ponto cantado, Oxum Puro Amor ${ }^{8}$.

\footnotetext{
${ }^{7}$ Disponível em: https://www.youtube.com/watch?v=h-FIMYp0eAM

${ }^{8}$ Disponível em: https://www.youtube.com/watch?v=lLvRbQR9J3g
} 
O seu canto traz magia.

Deusa da fertilidade.

Traz amor e alegria,

pra nos dar felicidade [...]

Ora yeyeô.

Representando a Umbanda

o puro amor.

O arquétipo da Amante domina as narrativas em que essa Yabá se encontra, uma vez que, esta é vaidosa e se mostra em um processo de ficar atraente, carregando consigo seu espelho. As mulheres que entram em contato com Oxum procuram desenvolver seu lado intimamente emocional e sexual, encontrando nela, a personalidade descrita por Mark e Pearson (2001) como a regente de todos os tipos de amores humanos e encorajadora do crescimento e identificação com seu gênero. Nesse caso, auxilia as mulheres a se sentirem mais empoderadas.

Jung (2000) reforça que o elemento feminino presente no inconsciente é chamado de anima que é associada a características como a sensibilidade, sensualidade, ternura, vaidade e predomínio do emocional ao racional. Em seus estudos, Jung (2000) apresenta a teoria em que Anima e Animus são complementares na psique de cada indivíduo, sendo a representação feminina e masculina, sendo, a estrutura Anima, a representação feminina presente no inconsciente do homem e, Animus, a masculina correspondente na mulher. Dessa forma, o Animus e Anima são os aspectos opostos do gênero que não estão presentes no consciente, mas sim no inconsciente.

A qualidade amorosa de Oxum leva à tranquilidade e aumenta o prazer em viver de forma harmoniosa. Em sua mitologia e imagem simbólica, ela irradia sensualidade, delicadeza e exalta o corpo da mulher, principalmente, no aspecto maternal como os grandes seios, em consequência, reconhecemos nessa Yabá, a representação do feminino no arquétipo da Amante.

A jornada pessoal de cada mulher, seja qual for a idade, ditam aspectos emocionais e racionais que as levam a se relacionar com determinada Yabá. Destaca-se que pode haver a flexibilização no que tange a identificação, de forma que, um indivíduo pode se identificar como sábio e em outro momento como grande mãe. Jung (2000) explica que o arquétipo representa um conteúdo inconsciente, o qual, modifica-se através de sua conscientização e percepção que variam de acordo a consciência individual na qual se manifesta. Quando criança se têm prédisposições para formar o conteúdo psíquico que será ativado em determinadas situações no decorrer dos anos, por esse motivo, uma mulher, na fase adolescente, pode se identificar com Oxum e suas características de Amante. Já no estágio adulto, ela pode ter uma propensão a se 
assimilar com as características de independência e superação da Orixá Iansã, que tem como arquétipo, o Herói.

\section{CONSIDERAÇÕES FINAIS}

Ao longo do estudo, aqui, relatado, percebeu-se que cada comunidade relaciona-se, de forma distinta, com os arquétipos por meio do inconsciente coletivo que são apresentados em forma de mitos e símbolos. Jung (2000) afirma, em seus estudos, que o inconsciente não é de natureza individual e que os arquétipos, ali presentes, manifestam-se e variam de acordo com a consciência pessoal, quando são submetidos a situações proporcionais que ativam as características de cada arquétipo. Esse conceito estende-se à diversas situações como a relação de assimilação da mulher umbandista no culto às Yabás, por exemplo.

Ao observar a atuação dos Orixás femininos, ficou perceptível a relevância no papel da mulher dentro da Umbanda. As imagens simbólicas vindas da África são retratadas, mesmo que de forma renovada, sem perder a essência primitiva. Dessa maneira, os contos mitológicos Iorubás, ainda, fazem-se presentes e ratificam o papel de protagonismo da mulher, no qual, cada Yabá presente manifesta um arquétipo que são identificados pelas médiuns com tendências às características retratadas.

Percebeu-se, nesse estudo, que, de fato, há uma variedade arquetípica em cada Orixá, pois em seus mitos sagrados são apresentadas características diversas determinadas por cada situação. Porém, destaca-se um padrão predominante em cada Yabá, ressonante ao seu arquétipo. Dessa forma, mesmo que sofra interferência de outras características, prevalecem os atributos primários como Iemanjá que, sendo a Grande Mãe, possui traços também do Prestativo, mas prevalecendo, sempre, suas principais características de geradora e protetora que remetem à mãe. Além de Iemanjá como geradora, reconhecemos, também, em Nanã essa propriedade, porém, no caso da criação do homem. Ela foi quem transformou, com sua sabedoria, o barro em vida, expondo assim as aptidões do Mago. Esse arquétipo, [o Mago] em diversas lendas, aparece como uma espécie de auxiliar do Herói. Em sua jornada, o mito Iorubá, a essa personalidade [o Herói], é evidenciada na Yabá Iansã que é reconhecida no imaginário como guerreira, diferente de Oxum que ecoa sensualidade e delicadeza, sendo representada assim, sob o arquétipo do Amante.

Esse relato de pesquisa mostrou a importância da identificação dos arquétipos individuais de Orixás femininos para o processo de individuação das mulheres, fazendo com 
que elas se sintam conectadas com a religião, pois reconhecem conteúdos simbólicos pessoais nas entidades sagradas. Esse estudo, apesar de ter como foco principal as mulheres, engloba também o ser humano como um todo, pois se entende a partir da humanidade presente em cada indivíduo que a vivência pessoal interfere no modo como há essa identificação com os arquétipos.

Vale ressaltar ainda que esse estudo, dada a exiguidade do tempo e consequente extensão que o escopo da pesquisa alcançou ao longo da mesma, que ela não se encerra em si própria. Ou seja, ficaram ainda por responder, perguntas como: de que forma se dá a influência das Yabás no anima, que seria o lado feminino presente no inconsciente masculino, ou ainda, tecer um aprofundamento do estudo feminino incluindo a percepção das características da pomba-gira e até mesmo a relação dos Orixás com a homoafetividade. No entanto, esses questionamentos são a força motriz que conduzem esta pesquisadora a levar este estudo a níveis mais aprofundados, seja em uma pós-graduação lato sensu ou até mesmo stricto sensu.

\section{REFERÊNCIAS}

AZEVEDO, Janaina. Orixás na Umbanda. São Paulo: Universo dos Livros, 2010.

BARBOSA JÚNIOR, Ademir. O Livro Essencial de Umbanda. São Paulo: Universo dos Livros, 2014.

BIRMAN, Patrícia. O que é umbanda: coleção primeiros passos. Coleção Primeiros passos. 2. ed. São Paulo: Editora Brasiliense, 1985.

CORDEIRO, Andreza da S.; DAMÁZIO, Lucas P.; GERALDES JUNIOR, Gutemberg A. Arquétipos e mitologia: um estudo das imagens arquetípicas presentes na série american gods. 2019. 11 f. TCC (Graduação) - Curso de Publicidade e Propaganda, Satc, Criciúma, 2019. Disponível em: 
http://revista.uepb.edu.br/index.php/REVISOCIOPOETICA/article/view/4922. Acesso em: 08 maio 2020.

ELIADE, Mircea. Aspectos do Mito. Lisboa: Edições 70, 2000.

O Sagrado e o Profano e Essência das Religiões. São Paulo, Martins Fontes, 2001.

FREYRE, Gilberto. Casa-grande \& Senzala. 48. ed. Recife: Global, 2003.

JUNG, Carl Gustav. Os Arquétipos e o Inconsciente Coletivo. 2. ed. Petrópolis: Vozes, 2002.

O homem e seus símbolos. Rio de Janeiro: Nova Fronteira, 2008.

KRAMER, Heinrich; SPRENGER, James. O Martelo das Feiticeiras: malleus maleficarum. Rio de Janeiro: Rosa dos Tempos, 2014.

MARKS, Margaret; PEARSON, Carol S. O Herói e o Fora-da-Lei. São Paulo: Pensamento Cultrix, 2001.

PRANDI, Reginaldo. Mitologia dos Orixás. São Paulo: Companhia das Letras, 2001.

SARACENI, Rubens. Os Decanos: os fundadores, mestres e pioneiros da Umbanda. São Paulo: Madras, 2003.

VOGLER, Christopher. A Jornada do Escritor: estruturas míticas para escritores. 2. ed. Rio de Janeiro: Nova Fronteira, 2006. 